УДК 37.018 .46

DOI:

Олена Кохановська, доктор педагогічних наук, доиент кафедри теорії й методики викладання навчальних дисииплін Комунального вищзого навчального закладу “Херсонська академія неперервної освіти”' Херсонської обласної ради

Ніна Слюсаренко, доктор педагогічних наук, професор, професор кафедри педагогіки, психології й освітнього менеджменту імені професора $Є$. Петухова Херсонського державного університету

\title{
ВИКОРИСТАННЯ ЗАСОБІВ ЦИФРОВОЇ ДИДАКТИКИ У ПІСЛЯДИПЛОМНІЙ
} ПЕДАГОГІЧНІЙ ОСВІТІ

У статті проаналізовано сутність ичифрової дидактики як феномена сучасної освіти та можливості реалізації ї̈ засобів в умовах післядипломної педагогічної освіти. Надано характеристику ключових понять. Представлено порівняльний аналіз деяких категорій традиційної, “оциифрованої” та ичифрової дидактики (за В. Бліновим). Звернуто увагу на те, щуо застосування в освітньому процесі тих чи тих засобів ичифровоі дидактики залежить від поставленої мети. Наведено перелік найбільш популярних серед педагогів сервісів й платформ, які можна опанувати в умовах післядипломної освіти.

Ключові слова: дидактика; е-дидактика; оцифрована дидактика; ичифрова дидактика; засоби цчифрової дидактики; післядипломна педагогічна освіта.

Табл. 1. Лім. 17.

Olena Kokhanovska, Doctor of Sciences (Pedagogy), Associate Professor of the Theory and Methods of Educational Disciplines Department Communal Higher Educational Establishment "Kherson Academy of Continuing Education" of Kherson Regional Council Nina Slyusarenko, Doctor of Sciences (Pedagogy), Professor, Professor of the Pedagogy, Psychology and Educational Management Department named after the Professor Ye. Petukhov of Kherson State University

\section{USE OF DIGITAL DIDACTICS IN POSTGRADUATE PEDAGOGICAL EDUCATION}

The article analyses the essence of digital didactics as a phenomenon of modern education and possibility of implementing its tools in postgraduate pedagogical education.

The characteristics of such concepts as "e-didactics", "digitized didactics" and "digital didactics" have been given. Digital didactics has been interpreted by authors as a part of general didactics, the main subject of which is the system of education in the context of globalization. It is emphasized that this is not only the use of digital technologies for teaching and learning, but also a critical didactic understanding of their feasibility at different stages of the educational process.

The comparative analysis of some categories of traditional, digitized and digital didactics (according to V. Blinov) has been presented.

The subject of digital didactics has been defined as the organization of the learners' activities in the digital environment and learning motivation management.

The attention is drawn to the fact that the use in the educational process of certain means of digital didactics depends on the desired goal.

The list of the most popular services and platforms among teachers which are used in the organization of the educational process at general secondary education establishments has been given such as feedback services; services for creating online and video presentations; services for screencasting; services for creating interactive video; services for creating interactive online whiteboards, platforms for video conferencing, services for creating interactive worksheets, platforms for distance learning. The conclusion is made about the need for further renewal and transformation of the digital educational environment of postgraduate education, technologies, didactic tools and resources.

Further research prospects for the study of effective ways of using digital didactics in postgraduate education of teachers of various disciplines have been identified.

Keywords: didactics; e-didactics; digitized didactics; digital didactics; means of digital didactics.

П остановка проблеми. Сьогодні надзвичайно швидко в практику роботи закладів освіти різних рівнів та ступенів упроваджуються цифрові технології.

(C) О. Кохановська,

Н. Слюсаренко, 2020
Однак цьому процесові притаманні певна стихійність та відсутність концептуального аналізу змін, що відбуваються.

Розвиток інформаційно-цифрових технологій,

Молодь і ринок №6-7 (185-186), 2020 
поява нових ресурсів та дидактичного забезпечення сприяли поступовому використанню їх у роботі закладів освіти: від стихійного впровадження до формування локально-дидактичного досвіду застосування таких технологій, виникнення дидактико-технологічних практик та парадигм [10, 18]. Це поступово сформувало до стану “розфокусованого розмаїття” ресурсів та втрати педагогічного сенсу використання інформаційноцифрових ресурсів. Розуміння важливості цифрової складової в освіті спричинило необхідність трансформації чинної системи навчання.

Аналіз останніх досліджень і публікацій. В останні роки питання використання інформаційно-цифрових технологій стало предметом наукових студій багатьох вітчизняних науковців, серед яких передусім назвемо В. Бикова, А. Гуржія, М. Жалдака, В. Олійника, О. Спіріна та ін. Питання цифрової дидактики розглядається й такими науковцями, як: В. Блінов, Є. Ссеніна, I. Сергеєва та ін.

Мета статті - проаналізувати сутність цифрової дидактики як феномена сучасної освіти та можливості реалізації їі засобів в умовах післядипломної педагогічної освіти.

Виклад основного матеріалу. Нині в Україні, як і в усьому світі, відбувається стрімка цифровізація освіти. Цифрова освіта, як зазначає К. Краус, функціонує за рахунок цифрових технологій, що переважно реалізуються засобами Інтернетмережі [7, 49]. Широке використання інформаційно-цифрових технологій, значно трансформує можливості здобувача освіти у напрямі вибору персональних освітніх траєкторій, його самовизначення та самовдосконалення $[5,262]$.

На необхідності наскрізного застосування інформаційно-комунікаційних технологій як складової цифрової освіти у викладанні навчальних дисциплін та управлінні закладами освіти наголошено в Концепції “Нова українська школа”. Це приводить до висновку, що саме інформаційноцифрові технології є невід'ємним інструментом успішного функціонування закладу освіти [8].

В Україні 16 жовтня 2020 р. набуло чинності Положення про дистанційну форму здобуття повної загальної середньої освіти (наказ МОН від 08.09.2020 р. №1115). Це Положення розширює можливості для навчання учнів за дистанційною формою, а також для використання технологій дистанційного навчання в умовах інших форм отримання освіти.

Сьогодні, як і завжди, вчитель $є$ агентом позитивних змін в освіті. Поява значної кількості цифрових засобів навчання передбачає не лише вміння вчителя ними користуватися, а й перегляд традиційних підходів до викладання загалом. Реконцептуалізація дидактики із врахуванням діджиталізації освіти $є$ необхідною умовою ефективного застосування цифрових технологій на всіх ступенях освіти [12].

Нагадаємо, що ще в 80-х р. XX ст. В. Беспалько вказував на те, що “в сучасних умовах, коли комп'ютеризація педагогічного процесу стає найближчою перспективою, педагогічне проєктування - єдина умова його ефективної реалізації' $[2,13]$. Звісно, педагогічне проєктування має відбуватися з урахуванням усіх вимог дидактики.

Загальновизнано, що дидактика - це наука про формування життєвого досвіду людини в процесі навчання $[4,13]$.

У процесі історичного розвитку людства постійно змінюються цілі, зміст форми і методи навчання. Залежно від конкретного етапу суспільного розвитку вони можуть мати помірний або радикальний характер. На теперішньому етапі зміни, які відбуваються в освітньому процесі, можна назвати радикальними, тому, відповідно, можна говорити про виникнення нового виду дидактики - дидактики інформаційного суспільства (дидактики цифрової епохи, цифрової дидактики) [6, 153].

Дидактику цифрового навчання Дж. Д’Анджело пропонує називати e-Didactics, що можна потрактувати як цифрову дидактику [17].

Поняття е-дидактики розглядається багатьма сучасними вченими і визначається по-різному.

Як зазначає О. Пєчников е-дидактика - це частина дидактики, яка досліджує проблему навчання, темою вивчення якої є комп'ютер та його застосування [9]. Тобто, вчений звужує едидатику до спеціалізованих дисциплін.

За визначенням М. Чошанова, е-дидатика сукупність знань, процесів і стратегій, орієнтованих на гарантоване формування у процесі дистанційного навчання у здобувачів освіти таких компетенцій, які відповідали б конкретно заданому рівню їх засвоєння [13]. Автор передбачає е-дидатику лише для дистанційного навчання, що, на нашу думку, не повністю відповідає реаліям сьогодення.

На думку I. Фролова, е-дидактика - частина сучасної дидактики, що досліджує закони, закономірності, принципи і засоби електронного навчання, які застосовуються 3 метою дистанційного набуття компетенцій [14].

Отже, як бачимо, вчені вважають, що едидактика пов'язана саме 3 викладанням в електронному форматі.

Стосовно терміна “цифрова дидактика” маємо констатувати, що він виник порівняно недавно. 
Визначення сутності цього поняття можна зустріти переважно в закордонних виданнях. Наприклад, В. Блінов, Є. Ссеніна, І. Сергеєва зазначають, що цифрова дидактика - це наука про організацію процесу навчання в умовах цифрового суспільства [3, 3]. Науковці звертають увагу на те, що цифрова дидактика базується на основних поняттях і принципах традиційної (доцифрової) дидактики, доповнюючи і трансформуючи їх відповідно до умов цифрового середовища.

Факторами, які породжують потребу у цифровій дидактиці $є$ : цифрове покоління (нове покоління учнів, яка має особливі соціальнопсихологічні характеристики); нові цифрові технології, які формують цифрове середовище і розвиваються у ньому; цифрова економіка та породжені нею нові вимоги до педагогів $[3,3]$.

На нашу думку, так звану “цифрову дидактику” можна розуміти як частину загальної дидактики, основним предметом дослідження якої є система навчання в умовах глобальної цифровізації, тобто це не лише використання цифрових технологій для навчання та викладання, а й критичне дидактичне осмислення їх доцільності на різних етапах навчального процесу.

Окрім поняття “цифрова дидактика”, нині в науковому обігу та в педагогічній практиці послуговуються також терміном “оцифрована дидактика".

Під “оцифрованою дидактикою” В. Блінов (ураховуючи ступінь застосування інформаційноцифрових технологій) розуміє оцифрування традиційного навчального матеріалу. Це, на думку вченого, призводить до того, що педагог, користуючись оцифрованими засобами, швидше самовідсторонюється від процесу навчання [16].

Дійсно, починаючи з 90-х р. минулого століття, свого роду дидактичною модою виступає оцифровка традиційних лекцій, підручників, поурочних розробок, тестових систем контролю знань тощо. В усіх випадках для неефективної “оцифрованої” дидактичної практики характерні такі особливості: 1) використання в оцифрованому вигляді традиційних дидактичних елементів освітнього процесу (змісту, форм і методів навчання) без будь-якої принципової їх трансформації; 2) використання універсальних інформаційно-цифрових технологій, що не сфокусовані на розв'язання конкретних педагогічних завдань; 3) відсутність наукового осмислення перших двох моментів $[3,7]$.

Таким чином, в основі “оцифрованої” дидактичної практики лежить емпіричний взаємний підбір наявного “під рукою” дидактичного забезпечення (змісту, форм і методів) і найбільш доступних інформаційноцифрових технологій.

На відміну від “оцифрованоі” та традиційної дидактики, цифрова дидактика передбачає переосмислення й істотну трансформацію нинішнього освітнього процесу (табл. 1).

3 таблиці 1 видно, що цілі, зміст, методи, форми і засоби цифрової дидактики трансформовані відповідно потреб цифрового суспільства, особливостей цифрового покоління та педагогічних властивостей цифрових технологій.

Одним із найважливіших завдань цифрової дидактики є досягнення педагогічних цілей та

Таблиця 1.

\section{Порівняльний аналіз деяких категорій традиційної, “оцифрованої”} та цифрової дидактики (за В. Бліновим)

\begin{tabular}{|c|c|c|c|}
\hline $\begin{array}{l}\text { Дидактичний } \\
\text { компонент }\end{array}$ & $\begin{array}{l}\text { Традиційна } \\
\text { дидактика }\end{array}$ & $\begin{array}{l}\text { “Оцифрована" } \\
\text { дидактика }\end{array}$ & Цифрова дидатика \\
\hline $\begin{array}{l}\text { Цілі навчального } \\
\text { процесу }\end{array}$ & \multicolumn{2}{|c|}{$\begin{array}{l}\text { Засвоєння соціального досвіду в дидактичній } \\
\text { формі знань, умінь та навичок }\end{array}$} & $\begin{array}{l}\text { Підготовка до } \\
\text { ефективної } \\
\text { життєдіяльності в } \\
\text { умовах цифрової } \\
\text { економіки та } \\
\text { суспільства }\end{array}$ \\
\hline Зміст навчання & \multicolumn{2}{|c|}{$\begin{array}{l}\text { Продукти соціального досвіду в знаковій формі } \\
\text { навчальної інформації “знання” }\end{array}$} & $\begin{array}{l}\text { Різні способи } \\
\text { діяльності, які } \\
\text { необхідно засвоїти }\end{array}$ \\
\hline $\begin{array}{l}\text { Форми і методи } \\
\text { навчання }\end{array}$ & $\begin{array}{l}\text { Фронтальні аудиторні } \\
\text { та індивідуальні } \\
\text { самостійні }\end{array}$ & $\begin{array}{l}\text { Фронтальні, частково } 3 \\
\text { індивідуалізацією та } \\
\text { дефіцитом групових } \\
\text { форм }\end{array}$ & $\begin{array}{l}\text { Домінування групових } \\
\text { та індивідуальних форм } \\
\text { навчання, динамічних } \\
\text { форм }\end{array}$ \\
\hline Засоби навчання & $\begin{array}{l}\text { Підручник, друковані } \\
\text { засоби наочності, рідко } \\
\text { - реальні предмети }\end{array}$ & $\begin{array}{l}\text { Цифрові, які } \\
\text { використовуються } \\
\text { епізодично }\end{array}$ & $\begin{array}{l}\text { Цифрові (IKT, } \\
\text { метацифрові } \\
\text { комплекси) }\end{array}$ \\
\hline
\end{tabular}

Джерело: [16]. 
розв'язання актуальних проблем освітнього процесу засобами цифрових технологій, що передбачає безперервне комплексне осмислення їхного дидактичного потенціалу, а також пошук конкретних способів їх використання $[1,31]$.

Предмет цифрової дидактики - організація діяльності тих, хто навчається, в цифровому середовищі і управління навчальною мотивацією.

Невід'ємною складовою цифрової дидактики $€$ засоби навчання.

Історія свідчить, що кожен етап розвитку освіти характеризується появою нових засобів навчання. В умовах цифровізації навчання формується нове освітнє середовище на базі цифрових технологій. Як зазначає А. Хуторський, до основних дидактичних функцій засобів навчання належать, зокрема: компенсаторність (полегшення процесу навчання для викладача, зменшення витрат часу та сил викладача і тих, хто навчаються); інструментальність (раціональність та безпечність видів діяльності викладача та тих, хто навчається); інформативність (передача необхідної для навчання інформації); інтегративність (вивчення об'єкта, процесу, явища цілком або частинами) $[15,402]$. Отже, засоби цифрової дидактики спрямовуються на персоналізацію навчального процесу, а також передбачають інтегративну взаємодію суб'єкта та середовища.

Цифрове освітнє середовище - це комплекс умов і можливостей для навчання, розвитку, соціалізації, виховання людини. Те, якою мірою буде затребуваний і використаний педагогічний потенціал цього середовища, залежить від власної суб'єктної активності і навчальної самостійності здобувача освіти [3].

Значний ривок у розвитку цифрової дидактики відбувається нині, під час пандемії COVID-2019. Адже після термінового припинення традиційного навчання здійснено примусовий перехід до віртуального. Для подолання цієї навчальної кризи створено різні стратегії онлайн-навчання. Однак розширення глобального віртуального простору залежить від наявності технологічних активних засобів цифрової дидактики.

Основна проблема, яка постає перед педагогами: які засоби, як саме i коли використовувати, щоб забезпечити ефективне засвоєння знань учнями в “новому” онлайн форматі.

Сучасні дослідження щодо трансформації традиційної дидактики з урахуванням процесів діджиталізації (використання цифрових технологій) підкреслюють важливість розвитку інформаційноцифрової компетентності суб'єктів освітнього процесу.
Значна роль у цифровізації освіти відводиться вчителю як основному суб'єктові підготовки молодого покоління до подальшої життєдіяльності.

Саме тому заклади післядипломної педагогічної освіти сьогодні реалізують програми підвищення кваліфікації, спрямовані на розширення, поглиблення, оновлення професійних знань і вмінь учителів різних дисциплін відповідно до вимог ринку та досягнень науки і техніки. У змісті цих програм також передбачено опанування вчителями інформаційно-цифровими технологіями $[11,189]$.

На сьогодні більшість інститутів післядипломної педагогічної освіти та академій неперервної освіти використовують різні можливості цифрової освіти, зокрема проходження очно-дистанційних та дистанційних курсів підвищення кваліфікації на окремих платформах. Деякі заклади також пропонують у межах курсового та міжкурсового періодів проходження окремих фахових спецкурсів за запитами слухачів. Для цього використовуються Google-інструменти, платформи дистанційного навчання (наприклад, Moodle), технологія wiki, окремо розроблені й адаптовані продукти.

Застосування в освітньому процесі тих чи тих засобів цифрової дидактики залежить від поставленої мети. А доцільність використання конкретних інформаційно-цифрових засобів визначає нерозривний зв'язок трьох складових: теорії, практики та технологічних рішень.

Досвід доводить, що найбільшою популярністю серед педагогів користуються ті сервіси, опанувавши які (зазвичай на курсах підвищення кваліфікації), вони зможуть успішно організовувати навчальний процес у закладах загальної середньої освіти. Серед них, насамперед, такі:

- сервіси забезпечення оберненого зв'язку (Mentimeter, Kahoot, Quizizz, Quizlet, Socrative, Triventy, Quizalize, Google Форми та ін.);

- сервіси для створення онлайн та відеопрезентацій (Sway, Crello, Canva, Google Презентації, NaraKeet, iSpring, Prezi, PowToon, Moovly та ін.);

- сервіси для скрінкастингу (Youtube, Loom, Bandicam, RecordCast, Camtasia Studio та ін.);

- сервіси для створення інтерактивного відео (Learnis, PlayPosit, PlayBuz, H5P, LearningApps, Timeline, EdPuzzle, TedEd та ін.);

- сервіси для створення інтерактивних онлайндошок (Stoodle, Webroom, DrawChet, LinoIt, Padlet, Popplet, Miro та ін.);

- платформи длязабезпечення відеоконференцзв'язку (Zoom, Google Meet, Skype, Microsoft Teams, BigBlueButton, Cisco Webex); 
- сервіси для створення інтерактивних робочих аркушів (WizerMe, TeacherMade, LiveWorkSheets та ін.);

- платформи для організації дистанційного навчання (Moodle, Google Classroom).

Звісно, цей перелік не є вичерпним і постійно доповнюється новими ресурсами.

Окрема роль для підвищення професіоналізму вчителів належить неформальній освіті- масовим відкритим онлайнкурсам (МООС). що є “живим” інструментом пізнання та підвищення професіоналізму вчителів. На сьогодні існує значна кількість платформ, де розміщено багато безкоштовних та умовно безкоштовних онлайнкурсів. До них відносимо освітні платформи "На урок”, “Всеосвіта", EdEra, Prometheus, Coursera, ВУМ, Duolingo та ін.

Звичайно ж, ознайомлення педагогів у системі післядипломної освіти 3 вищезгаданими ресурсами має відбуватися не лише на технічному рівні, а й на дидактичному, із зазначенням конкретних напрямів доцільності їх використання в освітньому процесі.

Висновки. Таким чином, все вищевикладене приводить до висновків про необхідність подальшого оновлення і трансформації цифрового освітнього середовища післядипломної освіти, технологій, дидактичних засобів і ресурсів. Результати проведеного дослідження дають підставу стверджувати, що модернізація і цифровізація освіти реалізує нову дидактичну парадигму, пов'язану з цифровими освітніми технологіями і методиками навчання й передбачає позитивний ефект, зокрема у післядипломній педагогічній освіті.

Перспективи подальшого наукового пошуку полягають у дослідженні ефективних шляхів використання засобів цифрової дидактики у післядипломній освіті вчителів різних дисциплін.

\section{ЛІТЕРАТУРА}

1. Андрюхина Л. М., ЛомовцеваН. В., СадовниковаН. О. Концепты цифровой дидактики как основания проектирования опережающего образования педагогов профессионального обучения. Профессиональное образование и рынок труда. 2020. № 1. С. 30-43.

2. Беспалько В. П. Педагогика и прогрессивные технологии обучения. Москва, 1995. $336 \mathrm{c}$.

3. Блинов В.И., Есенина Е.Ю., Сергеева И.С. Цифровая дидактика профессионального образования и обучения (ключевые тезисы). Модернизация образования. СПО. № 3. 2019. С. 3-8.

4. Дидактика профессиональной школы : сборник научных статей / под ред. член корр. РАО Г.И. Ибрагимова. Казань : Изд-во “Данис”, ИПП ПО PAO, 2013. $146 \mathrm{c}$.

5. Зубко А. М., Жорова І. Я., Кузьменко В. В.,
Слюсаренко Н. В., Кохановська О. В. Інформаційнокомунікаційні технології як чинник розвитку професіоналізму педагогів у системі післядипломної освіти. Інформаційні технологї̈ $і$ засоби навчання. 2020. Том 77. № 3. C. 262-281. URL : https:// journal.iitta.gov.ua/index.php/itlt/article/view/3562

6. Ибрагимов Г. И. Электронная дидактика и электронное обучение: анализ сущностных характеристик. Информатизация образования 2015 : сборник материалов международной научнопрактической конференци (15-16 июня 2015 года, г. Казань, РФ) / сост. к.п.н Э. М. Рафикова / под ред.: д.м.н. И. Ш. Мухаметзянов, д.и.н. Р. Р. Фахрутдинов. Казань: ACO, 2015. $448 \mathrm{c}$.

7. Краус К. М. Імперативи формування цифрової освіти в Україні. Управління соціально-економічними трансформаціями у сучасному місті : матеріали Всеукр. наук.-практ. конфер. (27 лютого 2018). Київ : КУБГ, 2018. С. 49-51.

8. Нова українська школа. Концептуальні засади реформування середньої школи. URL : https:// mon.gov.ua/storage/app/media/zagalna\%20serednya/ nova-ukrainska-shkola-compressed.pdf

9. Печников А. Н. Е-дидактика: кому, зачем и в каком виде она нужна. Образовательные технологии и общество. 2013. № 4. URL : http://cyberleninka.ru/article/ n/e-didaktika-komu-zachem-i-v-kakom-vide-ona-nuzhna

10. Роберт И.В. Дидактика эпохи цифровых информационных технологий. Профессиональное образование. Столица. 2019. № 3. С. 16-26.

11. Слюсаренко Н. В. Особистісний освітній простір учителя. Психолого-педагогічні засади діяльності фахівия: історія, теорія, практика : матеріали II міжнародної науково-практичної конференції (18-19 вересня 2014 року, м. Херсон) / за ред. В. В. Кузьменка, Н. В. Слюсаренко. Херсон : КВНЗ “Херсонська академія неперервної освіти”, 2014. С. 186-190.

12. Человекоразмерное образование: актуальные проблемы педагогических практик : материалы научно-практической конференции, посвященной педагогическому наследию М.А. Данилова, Л.А. Степашко (приурочена к 90-летию со дня рождения Л.А. Степашко), 19 октября 2018 г. / [отв. редакторы: Е.Ф. Зачиняева, О.А. Македонская, Т.Ю. Селихова]. Владивосток : Изд-во Дальневост. федерал. ун-та, 2018. URL : http://www.instrao.ru/images/1 Treshka/News/1810

13. Чошанов М.А. Е-дидактика: новый взгляд на теорию обучения в эпоху цифровых технологий. Образовательные технологии и общество. 2013. №3. URL: http:// cyberleninka.ru/article/n/e-didaktika-novyy-vzglyad-nateoriyu-obucheniya-vepohu-tsifrovyh-tehnologiy

14. Фролов И.Н. E-didactics как теоретический базис электронного обучения. В мире научных открытий. 2011. T. 14. № 2. C. 135-142. URL : http://methodlip.livejournal.com/363.html

15. Хуторской А. В. Современная дидактика: учебник для вузов. СПб : Питер, 2001. 544 с.

16. Цифровая дидактика профессионального образования тенденции, технологии, люди. URL : http:/ /www.krirpo.ru/Documents/News_ref_2019/ Sergeev_IS.pdf 
17. D'angeLo G. From Didactics to E-Didactics. eLearning Paradigms, Models and Techniques. URL: http:/ /www.liguori.it/schedanew.asp?isbn=4067

\section{REFERENCES}

1. Andriukhina, L. M., Lomovtceva, N. V., \& Sadovnikova, N. O. (2020). Kontcepty tcifrovoi didaktiki kak osnovaniia proektirovaniia operezhaiushchego obrazovaniia pedagogov professionalnogo obucheniia [Concepts of digital didactics as the basis for the design of advanced education for professional education teachers]. Vocational education and the labor market, no.1, pp.30-43. [in Russian].

2. Bespalko, V. P. (1995). Pedagogika i progressivnye tekhnologii obucheniia [Pedagogy and progressive learning technologies]. Moscow, 336 p. [in Russian].

3. Blinov, V. I., Esenina, E. Iu., \& Sergeeva, I. S. (2019). Tcifrovaia didaktika professionalnogo obrazovaniia obucheniia (kliuchevye tezisy) [Digital didactics of professional education and training (key theses)]. Modernization of education, no.3, pp.3-8. [in Russian].

4. Ibragimova, G. I. (Ed.) (2013). Didaktika professionalnoi shkoly: sbornik nauchnykh statei [Didactics of the professional school: collection of scientific articles]. Kazan, 146 p. [in Russian].

5. Zubko, A. M., Zhorova, I. Ya., Kuzmenko, V. V., Slyusarenko, N. V., \& Kokhanovska, O. V. (2020). Informatsiino-komunikatsiini tekhnolohii yak chynnyk rozvytku profesionalizmu pedahohiv u systemi pisliadyplomnoi osvity [Information and communication technologies as a factor in the development of the teachers' professionalism in the system of postgraduate education]. Information technologies and teaching aids, Vol.77 (3), pp.262-281. Available at: https://journal.iitta.gov.ua/ index.php/itlt/article/view/3562 [in Ukrainian].

6. Ibragimov, G. I. (2015). Elektronnaia didaktika i elektronnoe obuchenie: analiz sushchnostnykh kharakteristik [E-didactics and e-learning: analysis of essential characteristics]. Informatizatciia obrazovaniia - 2015: sbornik materialov mezhdunarodnoi nauchno-prakticheskoi konferentci - Informatization of education - 2015. Proceedings of the International Scientific and Practical Conference. Kazan, 448 p. [in Russian].

7. Kraus, K. M. (2018). Imperatyvy formuvannia tsyfrovoi osvity v Ukraini [Imperatives of digital education formation in Ukraine]. Upravlinnia sotsialnoekonomichnymy transformatsiiamy u suchasnomu misti: materialy Vseukr. nauk.-prakt. konfer. - Management of socio-economic transformations in the modern city. Proceedings of All-Ukrainian Scientific-Practical Conference. Kyiv, pp.49-51. [in Ukrainian].

8. Nova ukrainska shkola. Kontseptualni zasady reformuvannia serednoi shkoly [The New Ukrainian School. Conceptual principles of secondary school reform]. Available at: https://mon.gov.ua/storage/app/ media/zagalna\%20serednya/nova-ukrainska-shkolacompressed.pdf [in Ukrainian].

9. Pechnikov, A. N. (2013). E-didaktika: komu, zachem i v kakom vide ona nuzhna [E-didactics: who needs it, why and in what form]. Educational technologies and sosiety, no.4. Available at: http://cyberleninka.ru/article/ n/e-didaktika-komu-zachem-i-v-kakom-vide-ona-nuzhna [in Russian].

10. Robert, I. V. (2019). Didaktika epokhi tcifrovykh informatcionnykh tekhnologii [Didactics of the digital information technology era]. Professional education. Capital, no.3, pp. 16-26. [in Russian].

11. Slyusarenko, N. V. (2014). Osobystisnyi osvitnii prostir uchytelia [Teacher's personal educational space]. Psykholoho-pedahohichni zasady diialnosti fakhivtsia: istoriia, teoriia, praktyka: materialy II mizhnarodnoi naukovo-praktychnoi konferentsii - Specialist's psychological and pedagogical principles: history, theory, practice. Proceedings of the 2 nd International ScientificPractical Conference. Kherson, pp. 186-190. [in Ukrainian].

12. Zachiniaeva, E. F., Makedonskaia, O. A., \& Selikhova, T. Iu. (Ed.) (2018). Chelovekorazmernoe obrazovanie: aktualnye problemy pedagogicheskikh praktik: materialy nauchno-prakticheskoi konferentcii, posviashchennoi pedagogicheskomu naslediiu M. A. Danilova, L. A. Stepashko (priurochena k 90-letiiu so dnia rozhdeniia L. A. Stepashko) [Human-dimension education: current problems of pedagogical practices. Proceedings of the International Scientific-Practical Conference, dedicated to the pedagogical heritage of M. A. Danilova, L. A. Stepashko]. Vladivostok. Available at: http:/ /www.instrao.ru/images/1Treshka/News/1810/[in Russian].

13. Choshanov, M. A. (2013). E-didaktika: novyi vzgliad na teoriiu obucheniia $\mathrm{v}$ epokhu tcifrovykh tekhnologii [E-Didactics: a new look at learning theory in the digital age]. Educational technology and sosiety, no.3. Available at: http://cyberleninka.ru/article/n/e-didaktikanovyy-vzglyad-na-teoriyu-obucheniya-vepohutsifrovyh-tehnologiy [in Russian].

14. Frolov, I. N. (2011). E-didactics kak teoreticheskii bazis elektronnogo obucheniia [E-didactics as a theoretical basis for e-learning]. In the world of scientific discovery, Vol.14 (2), pp.135-142. Retrieved from http://methodlip.livejournal.com/363.html [in Russian]

15. Khutorskoi, A. V. (2001). Sovremennaia didaktika: uchebnik dlia vuzov [Modern didactics: a textbook for universities]. St. Petersburg, 544 p. [in Russian].

16. Tcifrovaia didaktika professionalnogo obrazovaniia: tendentcii, tekhnologii, liudi [Digital didactics of professional education: trends, technologies, people]. Available at: http://www.krirpo.ru/Documents/ News_ref_2019/Sergeev_IS.pdf [in Russian].

17. D’angeLo, G. From Didactics to E-Didactics. ELearning Paradigms, Models and Techniques. Available at: http://www.liguori.it/schedanew.asp?isbn=4067 [in English].

Стаття надійшла до редакції 02.11.2020

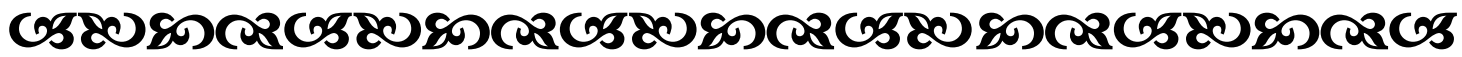

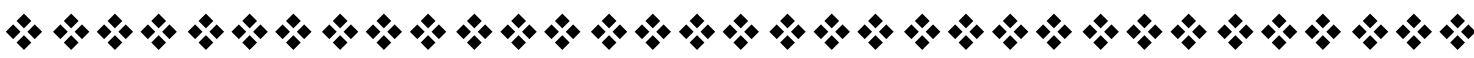

